\title{
Assessing the effect of tagging and the vulnerability to predation in tigerfish (Hydrocynus vittatus, Castelnau 1861) in a water-stressed system using telemetry methods
}

\begin{tabular}{|c|c|}
\hline \multicolumn{2}{|c|}{$\begin{array}{l}\text { Authors: } \\
\text { Bayanda Sonamzi }{ }^{1,2} \text { (D) } \\
\text { Matthew Burnett }{ }^{1} \text { (I) } \\
\text { Robin Petersen }{ }^{3} \text { (D) } \\
\text { Gordon O'Brien }{ }^{1,2} \text { (D) } \\
\text { Colleen T. Downs }^{1} \text { (D) }\end{array}$} \\
\hline $\begin{array}{l}\text { Affiliations: } \\
{ }^{1} \text { Centre for Fu } \\
\text { Biodiversity, S } \\
\text { Sciences, Uni } \\
\text { KwaZulu-Nata } \\
\text { Pietermaritzb } \\
\text { South Africa }\end{array}$ & $\begin{array}{l}\text { nctional } \\
\text { chool of Life } \\
\text { ersity of } \\
\text {, } \\
\text { urg, }\end{array}$ \\
\hline $\begin{array}{l}{ }^{2} \text { School of Bio } \\
\text { Environmenta } \\
\text { Mpumalanga } \\
\text { Nelspruit, Sou }\end{array}$ & $\begin{array}{l}\text { ogy and } \\
\text { Sciences, } \\
\text { University, } \\
\text { th Africa }\end{array}$ \\
\hline $\begin{array}{l}{ }^{3} \text { Scientific Ser } \\
\text { National Park } \\
\text { South Africa }\end{array}$ & $\begin{array}{l}\text { fices, Kruger } \\
\text { Skukuza, }\end{array}$ \\
\hline $\begin{array}{l}\text { Correspondin } \\
\text { Colleen Down } \\
\text { downs@ukzn }\end{array}$ & $\begin{array}{l}\text { g author: } \\
\text { s, } \\
\text { ac.za }\end{array}$ \\
\hline $\begin{array}{l}\text { Dates: } \\
\text { Received: } 13 \\
\text { Accepted: } 07 \\
\text { Published: } 17\end{array}$ & $\begin{array}{l}\text { uly } 2020 \\
\text { Oct. } 2020 \\
\text { Dec. } 2020\end{array}$ \\
\hline $\begin{array}{l}\text { How to cite th } \\
\text { Sonamzi, B., B } \\
\text { Petersen, R., } \\
\text { Downs, C.T., } 2 \\
\text { the effect of t } \\
\text { vulnerability t } \\
\text { tigerfish (Hyd } \\
\text { Castelnau } 186 \\
\text { water-stresse } \\
\text { telemetry me } \\
62(1) \text {, a1649. } \\
\text { org/10.4102/ } \\
\text { v62i1.1649 }\end{array}$ & $\begin{array}{l}\text { is article: } \\
\text { urnett, M., } \\
\text { 'Brien, G. \& } \\
\text { O20, 'Assessing } \\
\text { agging and the } \\
\text { o predation in } \\
\text { ocynus vittatus, } \\
\text { 1) in a } \\
\text { dystem using } \\
\text { hods', Koedoe } \\
\text { https://doi. } \\
\text { roedoe. }\end{array}$ \\
\hline Read online: & \\
\hline 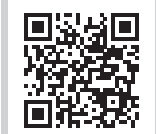 & $\begin{array}{l}\text { Scan this QR } \\
\text { code with your } \\
\text { smart phone or } \\
\text { mobile device } \\
\text { to read online. }\end{array}$ \\
\hline
\end{tabular}

Increase in anthropogenic pressures on freshwater ecosystems, globally and locally in South Africa, has made it difficult to meet environmental flow requirements and maintain these systems. The Letaba-Olifants catchment is one such example, where the upstream water demands place pressure on the river downstream as it flows through the Kruger National Park. We used the activity rates of Hydrocynus vittatus as a line of evidence to assess (1) the effects of telemeter tagging on their activity rates in three potential post-tagging recovery periods and (2) their vulnerability to predation and the causality related to the environmental stressors placed on the river catchment in the Olifants River Gorge, Kruger National Park, South Africa. We determined H. vittatus activity rates as locomotive movement using radio telemetry methods linked remotely to an online data management system. We telemeter tagged nine individuals from 08 May to 28 June 2018. However, only seven fish were successfully tracked for the duration of our study, and two individuals moved out of range of the remote network shortly after release and could not be located. The tagged $H$. vittatus individuals were found to have reduced activity at least within the first 7 days after tagging compared with the time after that. The results showed that three individuals were preyed on by predators after the tagging procedure recovery period. This coincided with abnormal low flow conditions, where the Letaba River ran dry. African fish eagles Haliaeestus vocifer were the only confirmed predator, whilst predation by other species was also evident.

Conservation implications: Monitoring of $H$. vittatus using telemetry is a viable tool to use when assessing environmental stressors in remote locations. The abnormally low water levels in the Olifants and Letaba Rivers (cessation of flow in the Letaba River) during our study may have compromised the predator avoidance strategies of tagged $H$. vittatus and may further be affecting the viability of the $H$. vittatus populations in Kruger National Park. The synergistic effects of natural and anthropogenic stressors impact negatively $H$. vittatus populations and potentially other aquatic biotas.

Keywords: fish behaviour; conservation; ecological indicators; environmental stressors; e-flows; fish recovery.

\section{Introduction}

Fish are well established around the world as indicators of ecological integrity (Harrison \& Whitfield 2006; Mims \& Olden 2013; Sosa-López et al. 2005). Similar to other aquatic organisms, fish species face several challenges from the environment they occur in and are subject to a plethora of stressors, both natural and anthropogenic (Du Plessis 2019; O'Brien et al. 2018). The ever-increasing anthropogenic pressures have generally led to a steady decline in aquatic organisms, including fish species (Dudgeon 2014; Rodell et al. 2018). Fish kills and population declines are often reported worldwide as a result of deteriorating aquatic ecosystems (Ferreira \& Pienaar 2011; Thronson \& Quigg 2008). This deterioration has been attributed to several factors, including river fragmentation, flow modification, pollution, the introduction of alien species and global climate change (De Moor 1996; Ellender \& Weyl 2014; O’Brien et al. 2019). Fish make use of the available physical habitat as refugia, for feeding and spawning, and as nurseries for their offspring (Godin 1997; O'Brien et al. 2013). Maintaining these environments is essential, but they are often inaccessible and difficult to sample, making observations hard to 
determine (Hussey et al. 2015; Lennox et al. 2017). Fieldbased studies are becoming increasingly important because of their holistic approach to measure animal behaviour and movements attributed to the environment they inhabit (Cooke \& Shcreer 2003; Cooke et al. 2017). Techniques such as capture-mark-re-capture (CMR) and environmental monitoring generally lack the representation of aquatic organisms' ecological interactions and fine-scale movements within their environments (Cooke et al. 2017). Increasingly telemetry techniques are being used to determine various stressors of aquatic organisms in the wild and their interactions with other organisms (Burnett et al. 2020; Cooke et al. 2004; Thorstad et al. 2013). Telemetry techniques are employed to monitor fish within their natural environment and can provide the required information needed to understand fish behaviour and fine-scale movements (Burnett et al. 2020; Wisniewska et al. 2016). Consequently, this technique has become the preferred method to study fish behaviour worldwide (Cooke et al. 2013; Hussey et al. 2015; Lennox et al. 2017). Recent developments in telemetry studies have presented opportunities for better management actions to safeguard the sustainability of natural resources (Abecasis et al. 2018; Block et al. 2016; Cooke et al. 2017).

Fish telemetry studies involve the attachment of electronic tags, and it has been shown that these affect the initial behaviour of tagged fish following tagging procedures (Økland et al. 2005). This has revealed that the predation of tagged fish is more likely to occur directly after the tagging procedure (Beland, Kocik \& Sheehan 2001; Halfyard et al. 2017; Schultz et al. 2017; Thorstad et al. 2003). In southern Africa, there have been reports of African fish-eagles, Haliaeetus vocifer, preying on telemeter tagged fish shortly after release (Burnett et al. 2020; Thorstad et al. 2003). Furthermore, the movement of telemeter tagged individuals does not always reflect normal behaviour until several days after tagging procedure, possibly the reason for the predation of individuals shortly after release (Thorstad et al. 2003). The predation effect on adult fish is generally unknown and can be exacerbated when using telemetry methods (Bolland et al. 2019; Moxham et al. 2019; Thorstad et al. 2003). Despite the above, the effects of telemeter tagging of fish are regarded as relatively minimal compared with the amount of information that is obtained through telemetry studies (Jepsen et al. 2002, 2004). The effect of predation, and other mortality accounts, after recovery from the telemeter tagging procedure, has largely been neglected, with mortality increasingly becoming an important consideration in aquatic telemetry studies (Klinard \& Mately 2020). These effects have been known primarily during the recovery period post-telemeter tagging procedure; however, predation thereafter could be higher than previously considered because of natural causes and environmental stressors (Jacobs 2017; Thorstad et al. 2003).

Anthropogenic changes to the environment take precedence in threatening local populations of fish within South Africa and elsewhere (Dudgeon et al. 2006; Rodell et al. 2018;
Woodborne et al. 2012). In recent years, there were increased studies within the Kruger National Park, particularly in the Olifants River, to understand the biological and ecological effects of anthropogenic stressors on various fish species and the Nile crocodile Crocodylus niloticus (Ashton 2010; Bouwman et al. 2014; De Villiers \& Mkwelo 2009; Ferreira \& Pienaar 2011; Smit et al. 2013). Moreover, telemetry has successfully been conducted on tigerfish Hydrocynus vittatus within southern Africa to determine their biology and ecology (Jacobs et al. 2019; O'Brien et al. 2012; Roux et al. 2018). These studies noted some interference of aerial predation on $H$. vittatus; however, none have specifically addressed the predation issue on $H$. vittatus post-telemeter tagging nor during recovery.

The tigerfish, Hydrocynus vittatus, is a relatively large, migratory Characin that is known to make extensive use of river reaches (Jacobs et al. 2019; Roux et al. 2018). Their higher trophic level and sensitivity to water temperature and oxygen levels make them good ecological indicators of environmental change in the riverine ecosystems they occur (Roux et al. 2018; Smit et al. 2013). They are listed as protected in the South African National Environmental Management of Biodiversity Act for Critically endangered, endangered, vulnerable and protected species (DEAT 2004). These characteristics make $H$. vittatus an ideal candidate for telemetry studies (Burnett et al. 2020; Jacobs et al. 2019; Jepsen et al. 2015). In the present study, we used the activity rates of $H$. vittatus as a line of evidence to assess (1) the effects of telemeter tagging on their activity rates in three potential post-tagging recovery periods and (2) their vulnerability to predation and the causality related to environmental stressors placed on the river catchment in the Kruger National Park, South Africa. We predicted that (1) H. vittatus are affected by the tagging procedure for only a few days and (2) the predation pressure on $H$. vittatus populations here would be higher than previously perceived. We then highlight the potential causalities of the increase in predation of $H$. vittatus based on environmental variables measured in the study area and similar environmental impacts elsewhere. The knowledge of natural stressors on $H$. vittatus populations can contribute to sound decision-making for their conservation and management and their river ecosystems. Understanding the impact of predation of fish species may explain the effect these predators have on the taxa and the aquatic environment.

\section{Study area}

The Letaba River, which originates in the Limpopo province of South Africa, joins the larger Olifants River in the Kruger National Park and then flows into Mozambique (Figure 1). Our study was conducted around the confluence of the two rivers. The Olifants River flows through the Gauteng, Mpumalanga and Limpopo Provinces. It is socioeconomically important and subjected to anthropogenic factors (e.g. intensive mining, industrialisation, urbanisation and agriculture) in most of its secondary 


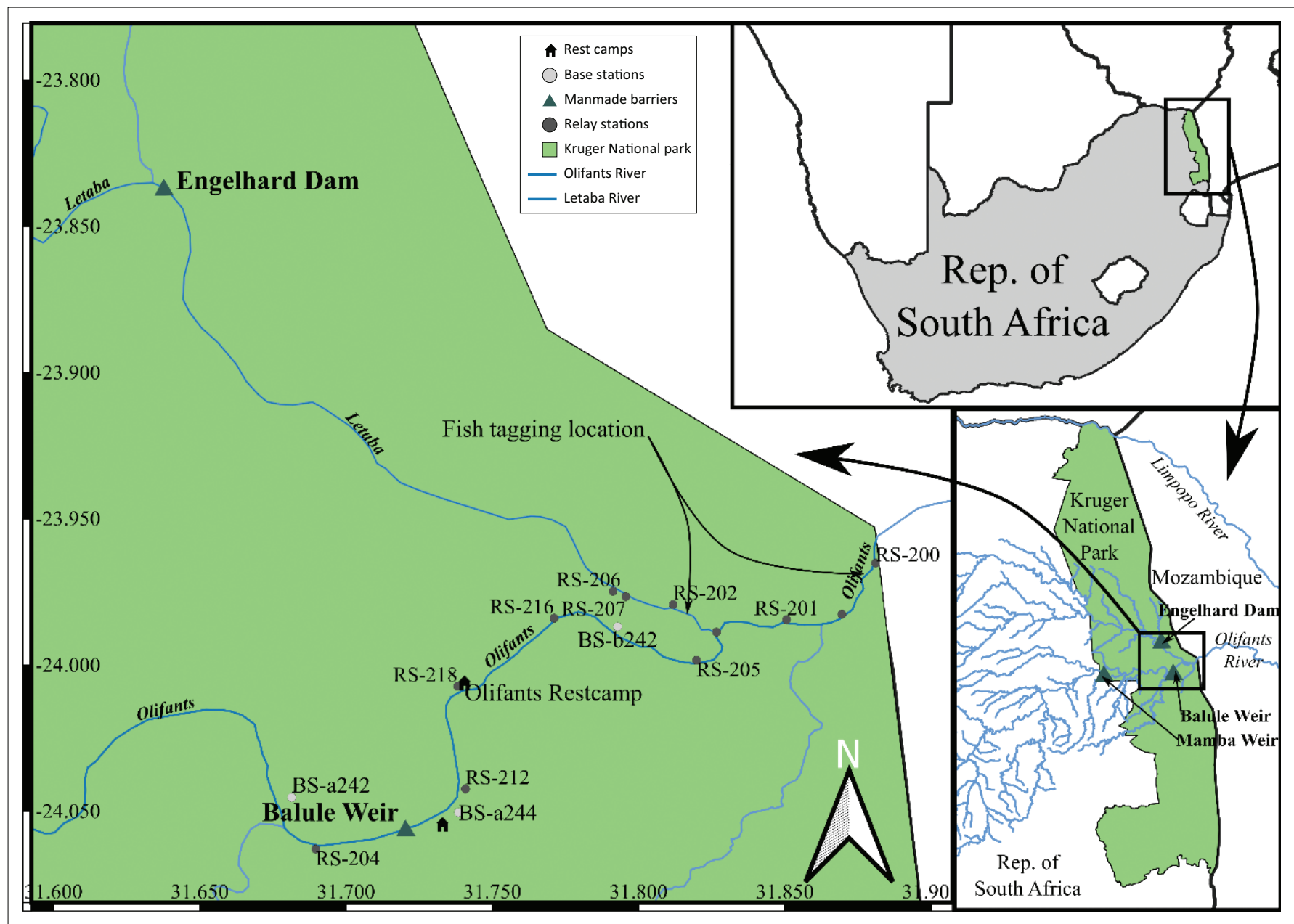

FIGURE 1: The Kruger National Park within South Africa and the positioning of the remote network consisting of base and relay stations. The hydrological gauging weirs at Balule and Engelhardt on the Olifants and Letaba Rivers, respectively, are shown.

catchments before it enters the Kruger National Park (De Villiers \& Mkwelo 2009; Gerber et al. 2016; Rogers \& O'Keeffe 2003). As a result, a wide range of environmental stressors impact the water quality and quantity entering the Kruger National Park, ultimately affecting the aquatic biota here (Du Preez \& Steyn 1992; Gerber et al. 2016; Roux et al. 2008). The Letaba River has anthropogenic impacts similar to the Olifants River that affect the water quality and quantity downstream (Rogers \& O'Keeffe 2003; Woodborne et al. 2012).

\section{Methods}

To track tagged $H$. vittatus individuals remotely and in real time, we established a remote network of receivers (base [BS] and relay [RS] stations) in the Olifants and Letaba Rivers (Figure 1) as per the Fish tracking (FISHTRAC) methodology described by Burnett et al. (2020).

\section{Capturing and tagging}

We captured nine adult $H$. vittatus using various techniques and methods that included electro-fishing, angling with artificial lures and the use of seine nets. The specimens were collected from 08 May to 28 June 2018 (Table 1).
After capture, body weight (where possible) and body length of the individuals were measured and recorded. In cases where this was not possible because of field technicalities, such as electronic scale failure, the body mass of the individuals was estimated using the standard length based on known measured body mass to length ratios, hence the use of an estimate (Table 1). According to Jepsen et al. (2004), tags weighing less than $2 \%$ of the fish body mass were used to ensure that the tag mass did not compromise the mobility of the subjects. Suitable individuals were anaesthetised in a water-filled container with a 0.4 millitres $(\mathrm{mL}) / \mathrm{L}$ concentration of clove oil. We observed for signs of anaesthesia before we commenced with the tagging as described by Burnett et al. (2020). These signs included, but were not limited to, reduced fin activities and involuntary upside-down swimming motions that were shown by the individuals (O'Brien et al. 2013). After that, we surgically attached Wireless Wildlife external radio tags (WW series IV) using sterilised hollow surgical needles to thread the tag attachment wire through the muscular tissue below the dorsal fin before removing them and securing the tag (Burnett et al. 2018; Jacobs, O'Brien \& Smit 2016). An antibiotic $\left(1.0 \mathrm{~mL} /\right.$ kilograms $[\mathrm{kg}]$ of Terramycin ${ }^{\circledR}$ containing oxytetracycline) was administered into the surrounding muscular tissue, followed by the application 
TABLE 1: Summary data for Hydrocynus vittatus individuals that were telemeter tagged in the Olifants Gorge, Kruger National Park, in the present study.

\begin{tabular}{|c|c|c|c|c|c|c|c|c|c|c|c|}
\hline \multirow{2}{*}{$\begin{array}{l}\text { Tag code } \\
455: 30\end{array}$} & \multirow{2}{*}{$\begin{array}{l}\text { Code } \\
\text { HVIT1 }\end{array}$} & \multirow{2}{*}{$\begin{array}{l}\text { Species } \\
\text { H. vittatus }\end{array}$} & \multirow{2}{*}{$\begin{array}{c}\begin{array}{c}\text { Standard } \\
\text { length }(\mathrm{mm})\end{array} \\
520\end{array}$} & \multirow{2}{*}{$\begin{array}{c}\begin{array}{c}\text { Body } \\
\text { mass }(\mathrm{g})\end{array} \\
3600\end{array}$} & \multicolumn{2}{|c|}{ Capture site (coordinates) } & \multirow{2}{*}{$\begin{array}{l}\text { Tagged } \\
\text { 08-May-18 }\end{array}$} & \multirow{2}{*}{$\begin{array}{l}\text { Last reported } \\
16-S e p-18\end{array}$} & \multirow{2}{*}{$\begin{array}{c}\begin{array}{c}\text { Days } \\
\text { tracked }\end{array} \\
131\end{array}$} & \multirow{2}{*}{$\begin{array}{l}\text { Fixes } \\
3117\end{array}$} & \multirow{2}{*}{$\begin{array}{l}\text { Comments } \\
\text { Last reported }\end{array}$} \\
\hline & & & & & $-23.959580^{\circ}$ & $31.881115^{\circ}$ & & & & & \\
\hline $455: 32$ & HVIT2 & H. vittatus & 420 & 1800 & $-23.980377^{\circ}$ & $31.811526^{\circ}$ & 10-May-18 & 03-Jul-18 & 54 & 1297 & Tag retrieved, predation \\
\hline $455: 33$ & HVIT3 & H. vittatus & 480 & \pm 2500 & $-23.980377^{\circ}$ & $31.811526^{\circ}$ & 10-May-18 & 06-Aug-18 & 88 & 2107 & Activity zero'd \\
\hline $455: 34$ & HVIT4 & H. vittatus & 445 & \pm 2000 & $-23.980377^{\circ}$ & $31.811526^{\circ}$ & 10-May-18 & 13-Oct-18 & 156 & 3731 & Last reported \\
\hline $455: 35$ & HVIT5 & H. vittatus & 410 & \pm 1700 & $-23.980377^{\circ}$ & $31.811526^{\circ}$ & 10-May-18 & 04-Jun-18 & 25 & 624 & Tag retrieved, predation \\
\hline $455: 36$ & HVIT6 & H. vittatus & 475 & \pm 2500 & $-23.980377^{\circ}$ & $31.811526^{\circ}$ & 11-May-18 & 13-May-18 & 2 & - & moved out of range \\
\hline $455: 37$ & HVIT7 & H. vittatus & 420 & \pm 1800 & $-23.980377^{\circ}$ & $31.811526^{\circ}$ & 11-May-18 & 31-Jul-18 & 81 & 1921 & Last reported \\
\hline $455: 38$ & HVIT8 & H. vittatus & 450 & \pm 2000 & $-23.985206^{\circ}$ & $31.830712^{\circ}$ & 28-Jun-18 & 20-Jul-18 & 22 & 554 & Predation \\
\hline 455:39 & HVIT9 & H. vittatus & 450 & \pm 2000 & $-23.995046^{\circ}$ & $31.805820^{\circ}$ & 27-Jun-18 & 30-Jun-18 & 3 & - & Moved out of range \\
\hline
\end{tabular}

H. vittatus, Hydrocynus vittatus.

of wound care gel (Aqua Vet, Veterinary Hospital, Lydenburg, South Africa) to minimise infection and assist with wound recovery (Burnett et al. 2020). After the tagging procedure was complete, we released the tagged individuals back into the river at their site of capture after signs of recovery were observed as detailed by Burnett et al. (2020). The tagging process from capture to tag attachment took $\sim<10 \mathrm{~min}$ per fish and at least $30 \mathrm{~min}$ was allocated for recovery from anaesthesia before releasing them into the river (at capture site).

\section{Data acquisition and analyses}

The telemeter tags used house omnidirectional tilt vibration sensors that are programmed to record motion as integer counts per unit time (Burnett et al. 2020). Motion is an inherent attribute of activity, and as such, these integer counts can be used as measures for locomotive movement recorded as activity rates (Burnett et al. 2020; Horn et al. 2011). Based on this concept, one of the assumptions in this study was that if a tag detects no motion and this persists, the tagged individual is assumed to be dead or the tag has been expelled.

We set telemeter tags to record data hourly and transmit the stored data when in range of a station $(<500$ metres [m]) to a central data management system (DMS). Each data point from the telemetry tag recorded the activity rate, water temperature $\left({ }^{\circ} \mathrm{C}\right)$, time, the station that detected the tag and the signal strength. The data were downloaded from the DMS and then processed and analysed in MS-Excel@ and R programming (RStudio Team 2020). The data were analysed descriptively using non-parametric tests. We compared our three hypothesised recovery periods using the KruskalWallis test for significance (McKight \& Najab 2010). We used principal components analysis (PCA) to describe activity groupings immediately after the fish were released accounting for the consecutive days post-tagging procedure (Bengraïne \& Marhaba 2003; Nasir et al. 2011; O’Brien et al. 2009; Van Den Brink, Van Den Brink \& Ter Braak 2003). The PCA allows for the analyses of large, complex data sets and accounts for individual variability in a linear response model relating activity rates against environmental variables and time periods (Nasir et al. 2011; Skalski, Richins \& Townsend 2018).
When activity rates monitored recorded zero, we tracked the respective telemetered tags on foot using a WW mobile receiver connected to an omnidirectional Yagi antenna (WW, Potchefstroom, South Africa) to determine their location and status. We retrieved the telemeter tag where possible. We carried this out in the study area using triangulation, that is, gain reduction between the telemeter tag in consideration and the mobile receiver as detected through the directional antenna (Burnett et al. 2020).

\section{Flow data}

We acquired the hydrological data from the South African Department of Water and Sanitation (DWS) website (http:// www.dwa.gov.za/Hydrology/Verified/hymain.aspx) for the gauging stations at Balule Weir (17.8 kilometres [km]; DWS Weir No. B7H026) on the Olifants River and Engelhardt Weir (27 km; DWS Weir No. B8H018) on the Letaba River.

\section{Ethical consideration}

All ethical standards were followed for the research and ethical clearance was obtained for the surgical tagging procedure of fish species from the relevant authority before the commencement of the study (University of KwaZuluNatal Animal ethics permit no. AREC/070/017D). Permission to sample and conduct the study in the Olifants River system was obtained from SANParks.

\section{Results}

We captured and tagged a total of nine adult $H$. vittatus individuals, with a mean ( \pm standard deviation [SD]) standard length of $452 \mathrm{~mm} \pm 35 \mathrm{~mm}$. Of these, we successfully tracked and monitored seven (Table 1). Two tags (HVIT 6 and HVIT 9) went out of range immediately after release and did not contribute to the data collected (Table 1). Telemeter tagged $H$. vittatus were monitored for a minimum of 22 days, with the longest tracked for 156 days (mean \pm SD: $66 \pm 52$ days). The variability in tracked days was because of the mortality of tagged individuals or fish moving out of the network range. The sample size for field studies met the criteria recommended by Sequeira et al. (2019), stating that individuals of $\leq 10$ should be used for studies that are still at an exploration phase, such as the present study. 
A typical activity pattern, as displayed by an $H$. vittatus individual (Figure 2), showed diurnal behaviour, with regular higher activity rates during the day when temperatures were warmer. This individual was tagged on 10 May and is indicative of the behaviour after recovery. The individual showed daily diel activity rates as they fluctuated throughout the study showing periods of lower activity rates interspersed with periods of higher activity rates, still maintaining a diurnal diel behavioural pattern.

\section{Recovery period}

We compared each of the hypothesised recovery periods (3, 7 and 14 days) with the remainder of the data set, excluding abrupt activity events before the cessation of activity rates where applicable. When the first potential recovery period was examined, there was a significant difference in the median of the activity rates between the data of the first 3 days and the rest of the data set (Figure 3). The activity rates

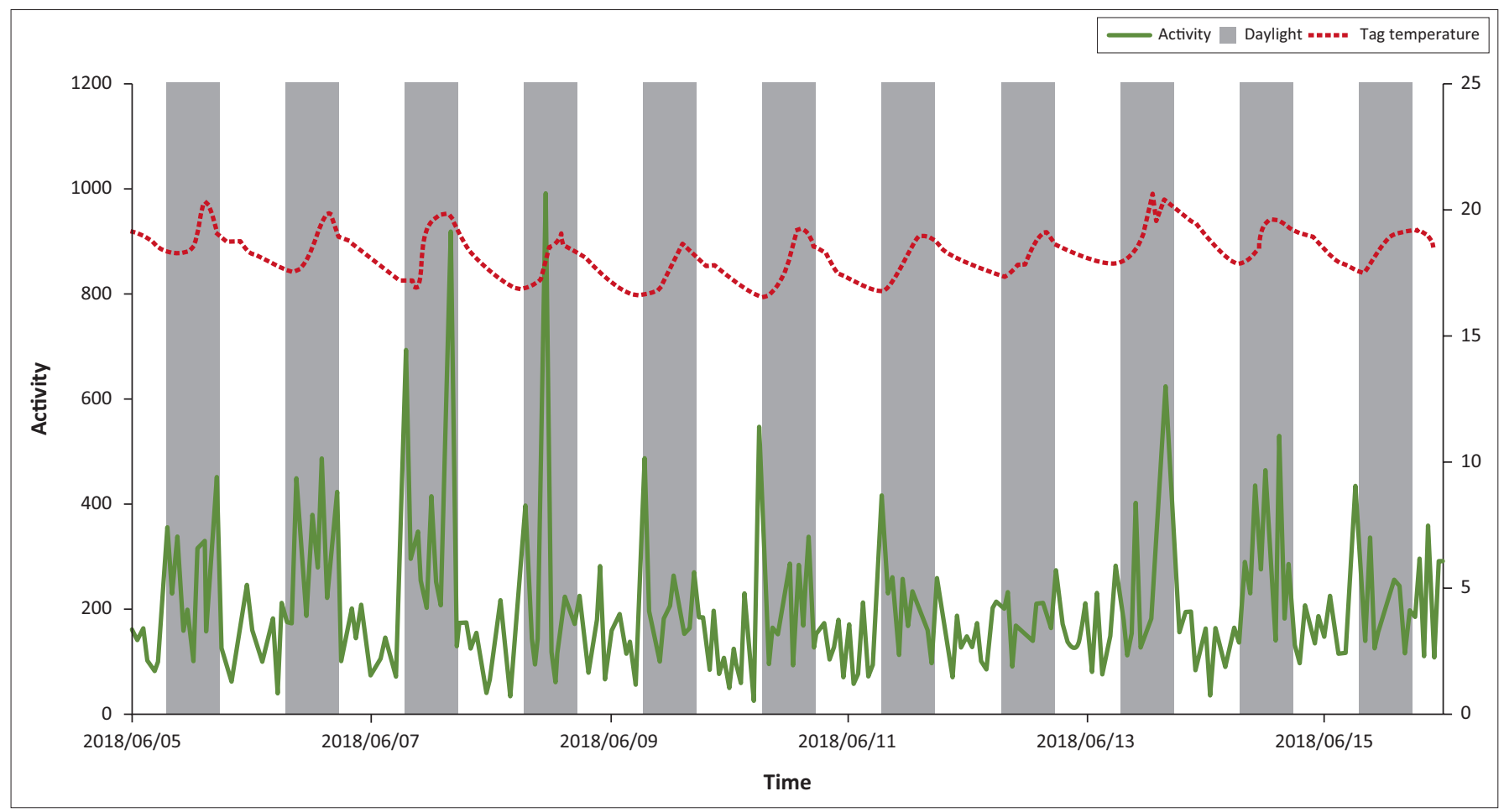

FIGURE 2: The daily behaviour of Hydrocynus vittatus as represented by the activity rates of individual HVIT3 (Table 1) showed typical fluctuations of activity rates, highlighting the diel behavioural pattern between night (non-shaded) and day (shaded).

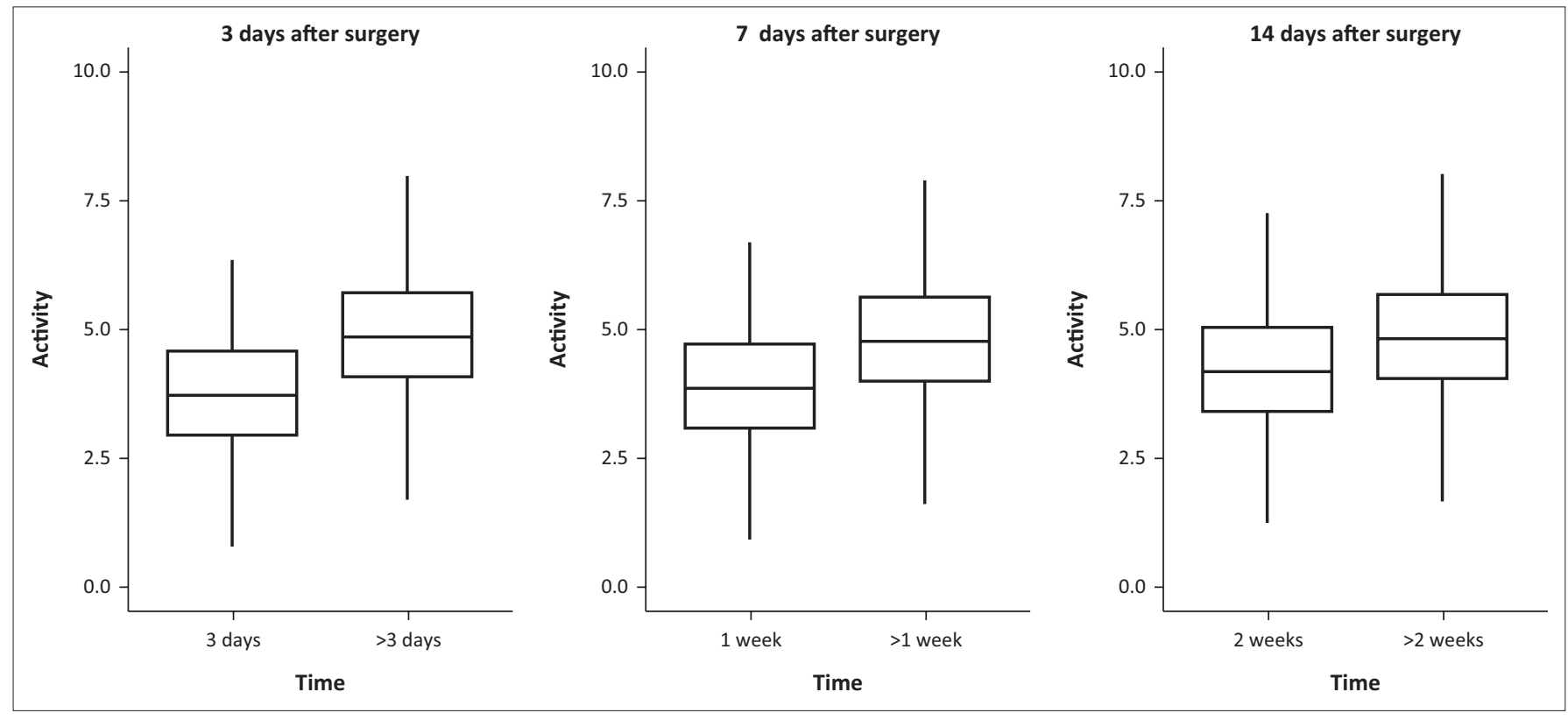

FIGURE 3: Box and whisker plots comparing the logarithmic activity rates of Hydrocynus vittatus individuals during the three potential recovery periods. The activity rates amongst the recovery periods were significantly different from the activity rates following each period $(p<0.05)$. Note: Median is denoted by the thick middle line of the box. The upper and lower limits of the box represent the first and third quartiles. 
of the initial first 3 days were lower than the activity rates after that (Table 2). Except for HVIT5 and HVIT7, this difference was statistically significant $(p<0.05$; Table 2$)$. Similarly, for the 7- and 14-days recovery periods assessed, all fish activity rates were shown to be significantly different $(p<0.05$; Table 2$)$, showing a lower activity rate in comparison with the stipulated recovery period (Figure 3 ). The activity rates for all telemeter tagged individuals combined showed an exponential increase in activity rates until the 14-day period (Figure 4); after this period, the activity rates fluctuated, indicating normalisation of activity rates for tagged individuals. The fluctuation in activity after 14 days decreased to a level similar to the day 7 post-tagging procedure (Figure 4a). This indicated that the effect of the tagging procedure was negligible after 7 days. This was

TABLE 2: A summary of the difference between activity rates between the three hypothesised recovery periods and the rest of the activity rates for the rest of the data set in the present study.

\begin{tabular}{lcccc}
\hline Individual & Total days monitored & 3 days & $\mathbf{7}$ days & $\mathbf{1 4}$ days \\
\hline All & 156 & $2.00 \mathrm{E}-16^{*}$ & $2.00 \mathrm{E}-16^{*}$ & $2.00 \mathrm{E}-16^{*}$ \\
HVIT1 & 131 & $2.00 \mathrm{E}-16^{*}$ & $2.00 \mathrm{E}-16^{*}$ & $2.00 \mathrm{E}-16^{*}$ \\
HVIT2 & 54 & $4.50 \mathrm{E}-09^{*}$ & $2.00 \mathrm{E}-16^{*}$ & $2.90 \mathrm{E}-12^{*}$ \\
HVIT3 & 88 & $2.40 \mathrm{E}-14^{*}$ & $2.00 \mathrm{E}-16^{*}$ & $0.00051^{*}$ \\
HVIT4 & 156 & $8.10 \mathrm{E}-15^{*}$ & $2.00 \mathrm{E}-16^{*}$ & $2.00 \mathrm{E}-16^{*}$ \\
HVIT5 & 25 & 0.22 & $1.80 \mathrm{E}-09^{*}$ & $2.90 \mathrm{E}-10^{*}$ \\
HVIT7 & 81 & 0.81 & $5.60 \mathrm{E}-06^{*}$ & $3.00 \mathrm{E}-12^{*}$ \\
HVIT8 & 22 & $2.00 \mathrm{E}-16 *$ & $2.00 \mathrm{E}-16^{*}$ & $2.00 \mathrm{E}-16 *$ \\
\hline
\end{tabular}

$*, p<0.05$.
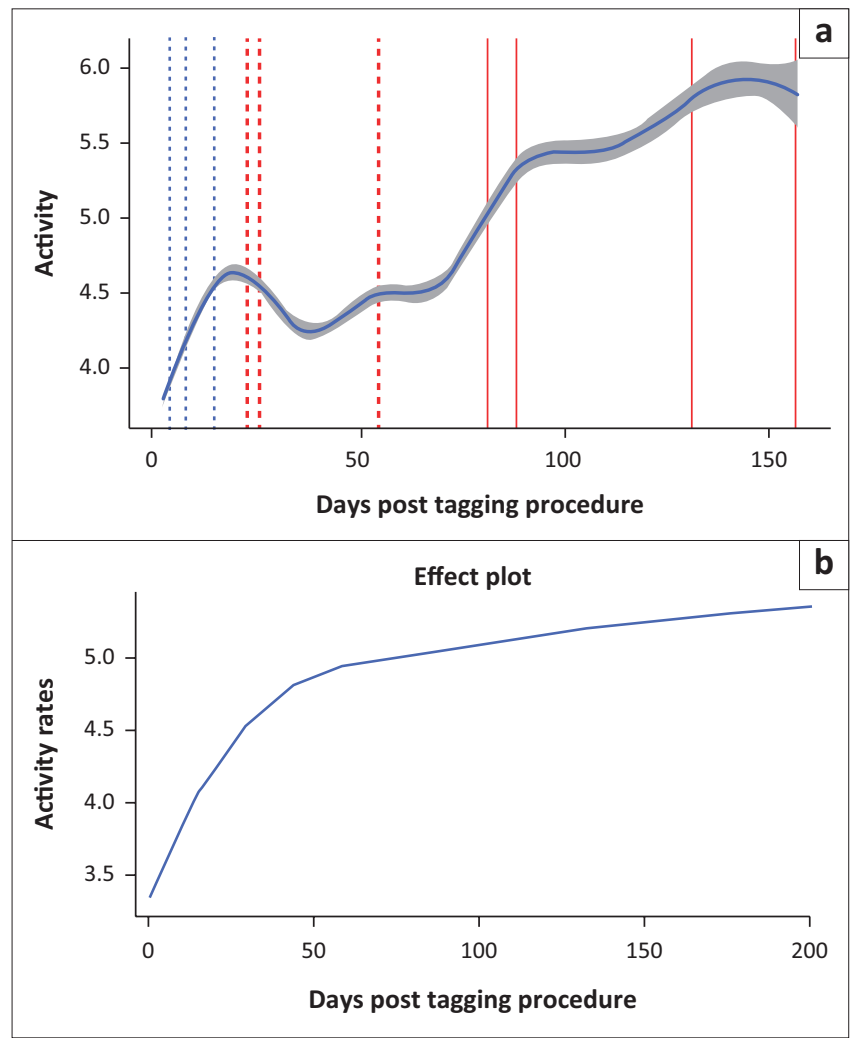

FIGURE 4: The logarithmic activity rates post-tagging of all telemetered Hydrocynus vittatus individuals in the present study where (a) shows the linear regression relationship and (b) the logarithmic regression relationship. In (a) the blue dotted lines represent the recovery periods tested ( 3 days, 1 week and 2 weeks after tagging), the red dashed lines highlight when the death of a fish was detected, and the solid red lines indicate when the signal was lost. consistent with the PCA analyses that showed a change in behaviour post-tagging, highlighting alternative variables affecting the activity rates of fish (Figures 4 and 5). The analyses showed that $71 \%$ of the individuals $(n=5)$ exhibited significantly low activity rates during the first $24 \mathrm{~h}$. All individuals showed significantly low activity during the 7- and 14-days monitoring periods.

\section{Predation events}

On 03 July 2019, tagged individual HVIT2 recorded a spike in activity and shortly after that the activity rapidly decreased to zero, indicating cessation of activity and possible mortality (Figure 6a). After this event, the telemeter tag also recorded temperatures no longer associated with the aquatic environment. We manually tracked the telemeter tag and found it $\sim 300 \mathrm{~m}$ from the riverbank under a feeding roost of an $H$. vocifer. Scattered fish bones surrounded the telemeter tag (Figure 7a; personal observation). Outputs from individual HVIT5 on 04 June were similar to HVIT2 and demonstrated changes in temperature and activity rates no longer associated with the aquatic environment and the tagged individual, respectively (Figure 6b). Manual tracking found the telemeter tag to be $\sim 1 \mathrm{~km}$ from the river.

Individual HVIT8 was monitored for approximately a month until two spikes in the activity rates that happened

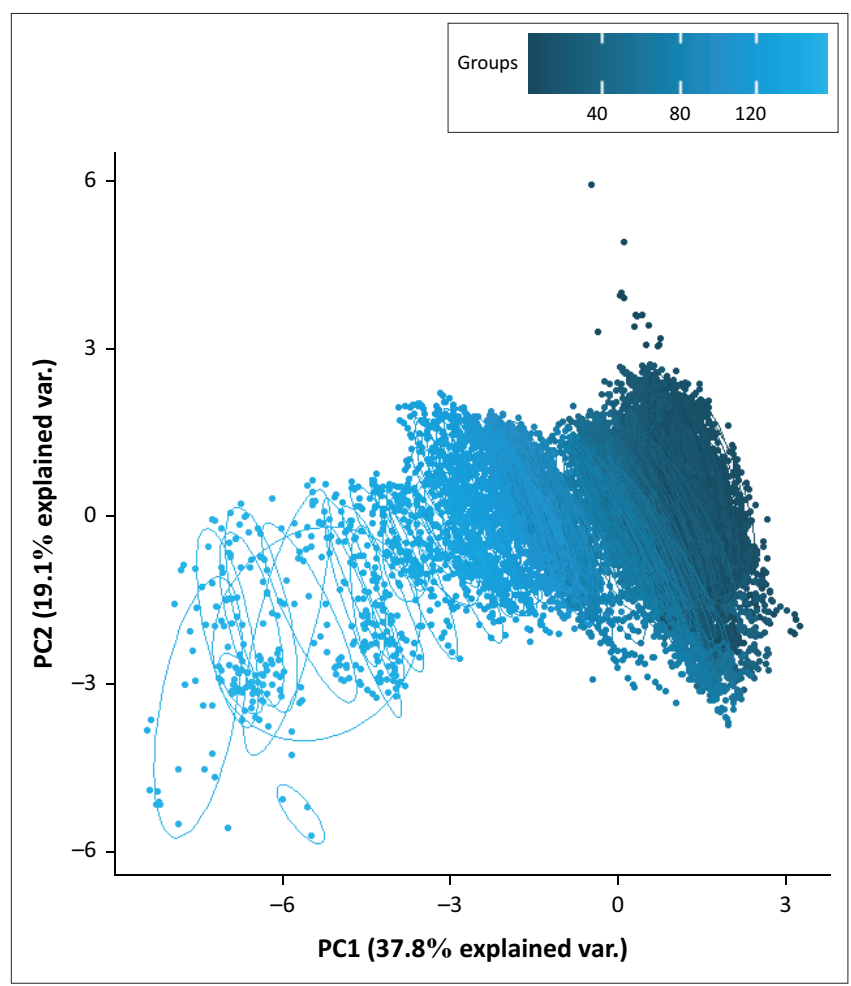

Note: Each dot is an activity rate data point and corresponds with a relevant grouping based on the colour scale. The lower end of the colour scale depicts a high cluster of activity rates centred around the period post-tagging.

FIGURE 5: Principal components analysis plot explaining $57.9 \%$ of variance between the activity rates after the tagging procedure and the time of day across the entire data set of all telemetered Hydrocynus vittatus individuals in the present study. The principal components analysis used the activity rates of fish, the time of day (PC1) and the day after the tagging procedure (PC2) to visualise the relationship between these three variables. 
on 20 July 2018 were recorded (Figure 6c). The initial spike brought the telemeter tag out of the aquatic environment for $24 \mathrm{~h}$, and the second spike moved the telemetered tag out of range of the network. These spikes, similar to individuals HVIT 2 and HVIT 5, indicated some form of a predatory event resulting in mortality of the tagged individual (Figure 6c). This predation event took place at night, without removing the fish from the vicinity of the riverbed, with the second activity spike moving the telemetered tag back into the water below detectable limits of the network, given adequate network coverage in the area.
The river flow dynamics of the Olifants and Letaba Rivers during the time of tracking and monitoring of $H$. vittatus are shown in Figure 6d. The water discharge in the Olifants River was $\sim 14 \mathrm{~m}^{3} \mathrm{~s}^{-1}$ but decreased steadily from May through to September whilst the Letaba River had substantially low flows $\left(\sim 1.4 \mathrm{~m}^{3} \mathrm{~s}^{-1}\right)$ and eventually ceased to flow, leaving behind scattered pools (Figures $6 \mathrm{~d}$ and $7 \mathrm{~b}$ ). The water discharge for the Olifants River at Balule Weir ranged between $14.10 \mathrm{~m}^{3} \mathrm{~s}^{-1}$ and $0.78 \mathrm{~m}^{3} \mathrm{~s}^{-1}$, whilst the Letaba River at Engelhardt Gauging Weir received between $1.20 \mathrm{~m}^{3} \mathrm{~s}^{-1}$ and $0.30 \mathrm{~m}^{3} \mathrm{~s}^{-1}$ during the study period, drying up entirely in places downstream of the study, as observed during manual monitoring surveys (Figures $6 \mathrm{~d}$ and $7 \mathrm{~b}$ ).

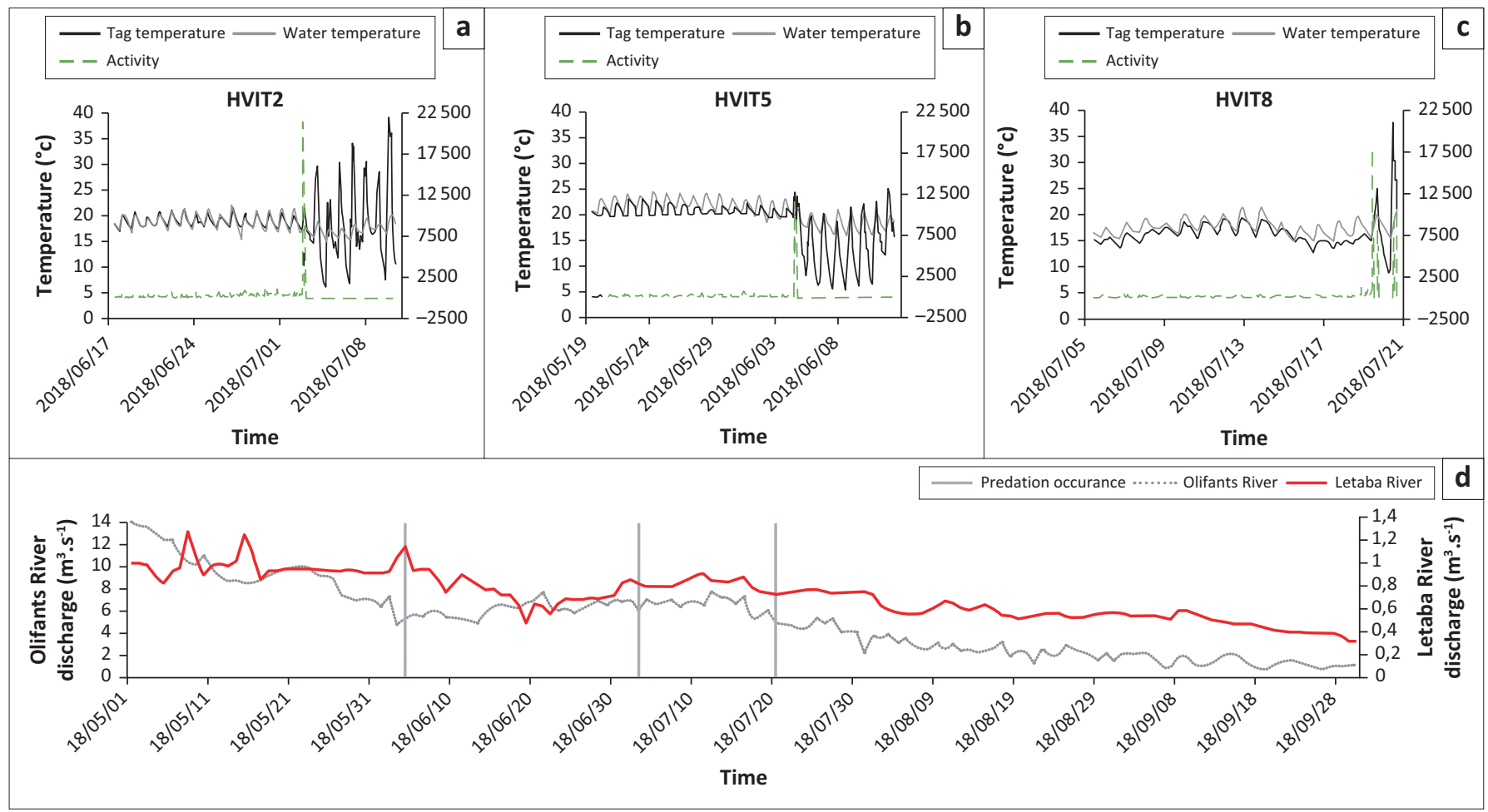

FIGURE 6: Hydrocynus vittatus activity rates with the change in environmental variables in the present study where (a), (b) and (c) show individuals' associated tag activity rates (dashed green) shown alongside the tag (grey) and water (black) temperatures $\left({ }^{\circ} \mathrm{C}\right.$ ), whilst (d) shows verified daily average flows from the Department of Water and Sanitation of South Africa at the points (grey bars) at which the predation events took place.
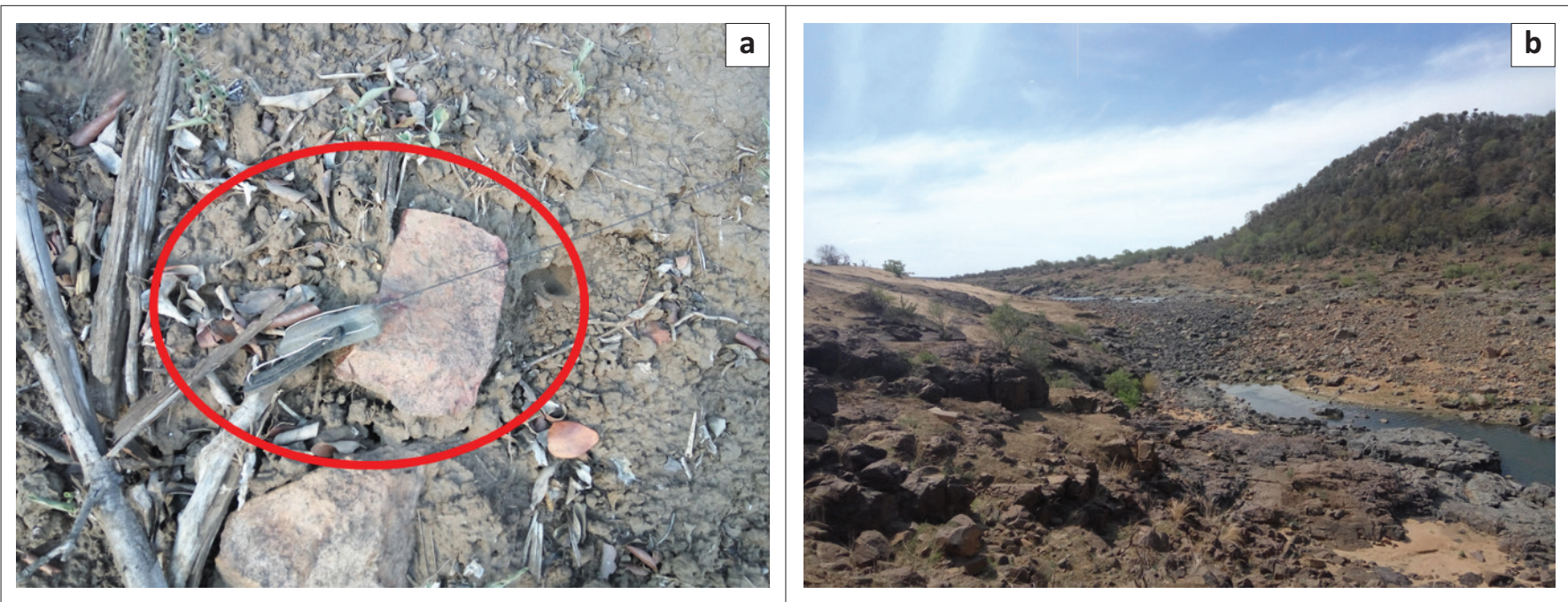

FIGURE 7: These photographs depict (a) the recovered telemetry tag (Tag32: HVIT2) as found by researchers (circled) and (b) no flow on the Letaba River downstream of Engelhardt Weir during the telemeter tag recovery survey. 


\section{Discussion}

In our study, we successfully showed the effects of telemeter tagging on the post-tagging activity rates of $H$. vittatus. Typically, the impact of the tagging procedure on tagged fish species in their natural environment is difficult to measure because of the limited in situ measurements and the inability to provide a control experiment (Frank et al. 2009, Jacobs et al. 2019). Despite this, we showed that the fine-scale variability in the movement was evident between different days in the study. This indicated that the response of $H$. vittatus was unique per day, and effects from the tagging procedure were no longer reflective from as early as 3 days post-tagging procedure, as shown in our linear model and the PCA analyses. This supports Jepsen et al.'s (2004) finding that the minimal disturbance in fish behaviour is seen during recovery, and the tagging procedure may only affect behaviour within 7 days post-tagging. Knowing that the tagging procedure is regarded as a stressor on the behaviour, the fish will navigate its recovery whilst maintaining daily circadian rhythms whilst facing associated environmental conditions. Although none of the individuals were predated with 14 days after the tagging procedure, this period of recovery suggests that telemeter tagged $H$. vittatus may be susceptible to predation as in other studies (Thorstad et al. 2003).

The minimum length of the recovery period for fish can be as short as $8 \mathrm{~h}$ to a day depending on the species, tagging methodology and the fish species' environment (Jepsen et al. 2002; Metcalfe et al. 2016). Økland et al. (2005) suggested 7 days, specifically for $H$. vittatus. Our study suggests that recovery can extend up to 14 days, however, but can be seen from as early as 3 days post-tagging procedure. On the contrary, the diel behaviour of tigerfish can return to normalcy within the 24-h period and may be crucial to the recovery of the fish. More recently, Jacobs et al. (2016) used upstream and downstream movement of $H$. vittatus to assess the immediate and long-term effects of telemeter tags and found that the movement of the individuals was predominantly downstream (60\%). This was associated with reduced spatial movement within the first 3 days of tagging. As such, tagging procedures have immediate effects ( $<3$ days after tagging) and minimal in the long term ( $>7$ days) (Jacobs et al. 2016; Jepsen et al. 2004). In our study, 2 weeks was shown to fall within the periods of an exponential increase in activity rates; however, fluctuations after this period fell as low as activity rates seen after 7 days. Paukert et al. (2001) found similar findings and concluded that activity patterns of individuals could be abnormal to up to 2 weeks following release after tagging. Although these studies (Jacobs et al. 2016; Økland et al. 2005; Paukert et al. 2001) used manual monitoring techniques, in our study, the activity rates showed that daily circadian rhythms were reflective of normal behaviour from within 3 days post-tagging. The fine-scale observations using activity rates in our study were conclusive. The activity rates of $H$. vittatus were not only reflective of their full recovery within 2 weeks of tagging but could also be indicative of their need to maintain biological processes (feeding and resting) as seen in the diel behavioural activity patterns. This supports the use of $H$. vittatus as suitable candidates for telemetry studies (Økland et al. 2005) and can be used to understand the response of the fish to environmental variables (Burnett et al. 2020).

The present study also used the activity rates of $H$. vittatus as a line of evidence to assess their vulnerability to predation and the causality related to flows and predatory events in inland aquatic ecosystems. Of the seven $H$. vittatus that were successfully monitored, three were removed by predators after the tagging procedure recovery periods tested. Through manual tracking and recovery of radio tags, the African fish eagle (H. vocifer) appeared to be a key predator of adult $H$. vittatus. This was supported by the activity rates for individuals HVIT2 and HVIT5 and their change in environments from the freshwater to terrestrial environments. During the tag recovery exercise, HVIT2 and HVIT5 tags were found below a feeding roost and surrounded by fish scales and bones, confirming that $H$. vocifer were the likely predators of $H$. vittatus. Real-time data showed that these events occurred during the day when $H$. vocifer and other piscivorous birds such as $P$. haliaetus were active, of which both are known to be diurnal species, the latter being migratory (Østnes et al. 2019; Stewart et al. 1997).

Notwithstanding $H$. vocifer being a common natural predator of $H$. vittatus, otters (Lutrinae family) and Nile crocodiles cannot be ruled out as potential predators as they are known to feed on fish (Games \& Moreau 1997; Rowe-Rowe 1977). As shown by HVIT8, a predation event took place at night, resulting in the tag being removed from the water and later returned to below detectable limits of the telemeter tag, given adequate network coverage in the area. The occurrence of this event at night suggests that a mesocarnivore like the Cape clawless otter (Aonyx capensis) were responsible as they are nocturnal predators, known to be common in the Olifants and Letaba Rivers (Pienaar 1964; personal observation). The high presence of piscivorous predators in our study area suggests the high impact of these predators on fish communities. Our study suggests that the impact of predation is considerably higher than what was initially thought and should be considered as a factor in disturbances to fish communities. Similar studies have shown this using an avian approach in estuaries (Cowley, Terörde \& Whitfield 2017), yet little is known about riverine ecosystems where predators are linearly spaced. This study suggests that predation on fish species is not solely avian related and that mammalian and reptilian predation could also be significant and should be considered especially for adult fish.

We acknowledge that one of the limitations in our study was the relatively small sample size, which was partly because of the cost of telemeter tags and accessibility to the field sites that limited the ability to increase the sample size. As such, larger sample sizes are recommended in further studies to improve confidence in using activity rates as a line of 
evidence and understanding the results shown here. In the present study, we were also limited to the use of adult fish because of the mass of the telemeter tag (20 grams [g]); thus, only individuals above $1000 \mathrm{~g}$ could be tagged as determined by the $2 \%$ tag to body weight ratio (Jepsen et al. 2002). Despite these restrictions, our findings provide inferred population responses, strengthening the cause and effect data associated with $H$. vittatus. Considering this, the results of our study are useful in the management of water resources, especially for downstream users such as the Kruger National Park, and can lay a foundation for future use of this technique.

The low flow observed in both rivers during the survey is also a matter of concern. One of the immediate results of these low flows, potentially resulting from water abstraction, dams and drought, is the formation of isolated pools with little to no flows (Pearce 2018). Stears and McCauley (2018) reported that during these low flow and dry periods, the lack of sufficient oxygenated water and removal of nutrients could cause oxygen levels to decrease and nutrients to reach toxic levels. Although not measured in the current study, Stears and McCauley (2018) reported that in hypoxic conditions oxygen-dependent fish species such as yellowfishes (Labeobarbus spp.) tend to swim close to the water surface where oxygen levels are comparatively higher, making them vulnerable to predators. Hydrocynus vittatus is known to use the entire water column to adapt to changes in food resources and water quality (O'Brien et al. 2014; Smit et al. 2013; Steyn et al. 1996). These adaptations to altering environmental conditions could increase their exposure to predators as they swim closer to the surface in hypoxic conditions (Stears \& McCauley 2018). Other opportunistic predators such as baboons Papio ursinus have been observed predating on stressed fish in these circumstances (Stears \& McCauley 2018).

Hydrocynus vittatus are oxygen-dependent species (Vignaud et al. 2002) and are likely to be under more pressure during periods of low flow when the river becomes fragmented into isolated pools than other species. They are also known to generally stay within their home ranges (Jacobs et al. 2019; Økland et al. 2005), with their movement often restricted by in-stream barriers (Roux et al. 2018). As such, they are more likely to be affected by low oxygen levels when trapped in isolated pools. The reduction in flows and in-stream barriers (dams and natural waterfalls) on both the Olifants and Letaba rivers resulted in relatively few opportunities for $H$. vittatus to move to reaches where flows were favourable. As observed in this study, this traps them in isolated pools until conditions improve or mortality ensures. This was supported by the remote network established for this study, not detecting reach scale movement of tagged fish. The reduction in water flows from both river systems coincided with the predation events, showing that flow stressors increase the risk to predation and the ecological degradation of the ecosystem for H. vittatus. Two main in-stream barriers (Engelhard and Mingerhout Weirs) upstream on the Letaba River form artificial barriers obstructing already low flow conditions and have no economic or biodiversity value for the lower
Letaba River system ( $\mathrm{O}^{\prime}$ Brien et al. 2019). Flows beyond these gauging weirs typically go unmonitored, and our study detected no flow in the Letaba River whilst Engelhard Dam recorded minimal flows at $<0.314 \mathrm{~m}^{3} \mathrm{~s}^{-1}$. The activity rates and predation events coincided with this reduction in the flow and susceptibility of $H$. vittatus to hypoxic conditions (Smit et al. 2013). This highlights the importance of maintaining environmental flows into the Olifants Gorge. The discrepancy in the flows between Engelhard Weir and the Olifants Gorge suggests that this weir cannot meet environmental flows downstream and questions the ability of the current infrastructure to adequately monitor and meet the environmental flow requirements for the Olifants and Letaba Rivers. With this, the Engelhardt Wier makes for a good case to be removed as it jeopardises the biodiversity in the Letaba River as with other such in-stream barriers (O'Brien et al. 2019). All-inclusive real-time and remote monitoring techniques have been developed to minimise the loss in river connectivity and monitor rivers, and these can continue to be implemented in the Olifants-Letaba Catchment (Burnett et al. 2020; Pollard et al. 2012).

\section{Conclusion}

Telemetry methods should, where possible, have larger sample sizes and make use of smaller and lighter tags $(<20 \mathrm{~g}$ air mass) with proportionally less body to tag mass ratios for adult fish. These recommendations will improve the confidence in results and the recovery process as well as increase the representable size classes in telemetry studies of this nature. This will further ensure the inclusion of smaller fish species as well as earlier life stages in telemetry studies. Our study also demonstrated that external telemeter tags affected the activity patterns of individuals in the short term ( $<3$ days) but minimal in the long term. Despite the stress caused by tagging, inadequate flows can contribute to the vulnerability of $H$. vittatus to predation, especially when environmental flows are not adequately maintained. The reduction in flows may play a role in increasing the risk of predation of $H$. vittatus and their overall condition in the freshwater environment. Similarly, additional environmental stressors may be compounded by reduced flows, and if not addressed, it would further jeopardise the population of H. vittatus in the Kruger National Park.

The excessive use of water resources by users upstream of the Kruger National Park (Dabrowski, Oberholster \& Dabrowski 2014; De Villiers \& Mkwelo 2009; Fouché 2008) is typically the main drivers of reduced flows in the downstream reaches of the Letaba and Olifants rivers. Although compounded by other environmental stressors, altered flows expose $H$. vittatus to predation, increasing the likelihood of such events during the low flow season when exacerbated by abstraction upstream. In our study, the extremely low flows observed in the Letaba River were further exacerbated by the presence of unused dams in the Kruger National Park, mainly Engelhardt Wier, that limited the release of water downstream. Its removal should be considered to contribute to maintaining low flows and the 
biodiversity in the Letaba River to ensure that environmental flow conditions for Kruger National Park and into Mozambique are met.

Setting environmental flows and implementing them could be the solution to the conservation and sustainability of $H$. vittatus in the Kruger National Park. Suitable allocations of environmental flows to the Letaba and Olifants Rivers will have a direct influence on this species by reducing environmental stress, avoiding predators and improving their general fitness. The fine-scale detection of activity rates recorded using the telemeter tagged fish could further contribute to an understanding of the response of fish to environmental conditions enabling long-term monitoring of anthropogenic stressors placed on these and other river systems.

The value of telemetry studies such as ours is that they can significantly assist in understanding the behavioural responses of fish species to environmental stressors, such as flows, and also other water quality parameters. Monitoring the behavioural responses in real time and remotely can further assist the implementation of environmental flows in ensuring optimal functioning of the ecosystems and increasing the output of ecosystem services provided by freshwater ecosystems. The conservation of $H$. vittatus is essential in South Africa as they serve as keystone species and meeting their requirements will assist in the conservation of other aquatic species maintaining the integrity of those freshwater ecosystems.

\section{Acknowledgements}

The authors are grateful to the South African National Parks (South Africa) staff members, especially game guards, for their contribution to the success of the project. They thank the reviewers for their constructive that improved this manuscript.

\section{Competing interests}

The authors have declared that no competing interest exists.

\section{Authors' contributions}

B.S., M.B., R.P., G.O.B. and C.T.D. conceptualised the study. G.O.B. and C.T.D. funded the study. B.S., M.B., R.P. and G.O.B. collected the data. B.S. and M.B. did the data analyses. B.S. and M.B. wrote the draft manuscript. R.P., G.O.B. and C.T.D. made contributions to this.

\section{Funding information}

The would like to thank the Water Accelerator Programme (WADER) (South Africa) and Water Research Commission (South Africa) for funding the FISHTRAC programme to monitor the water quality and flow variability, and fish response to these changes, in real time remotely in the Olifants River, Kruger National Park. They would also like to acknowledge the National Research Foundation (South
Africa) and the associated GLOWSENS project for providing operational support for this project. A further thanks to the University of Mpumalanga (South Africa) and the University of KwaZulu-Natal (South Africa) for funding this project. The authors also thank Idea-Wild (the United States of America) for equipment used in this study.

\section{Data availability statement}

The data are available on request from the corresponding author and are stored at the University of KwaZulu-Natal.

\section{Disclaimer}

The views and opinions expressed in this article are those of the authors and do not necessarily reflect the official policy or position of any affiliated agency of the authors.

\section{References}

Abecasis, D., Steckenreuter, A., Reubens, J., Aarestrup, K Alós, J., Badalamenti, F. et al., 2018, 'A review of acoustic telemetry in Europe and the need for a regional aquatic telemetry network', Animal Biotelemetry 6, 1-7. https://doi.org/10.1186/ s40317-018-0156-0

Ashton, P.J., 2010, 'The demise of the Nile crocodile (Crocodylus niloticus) as a keystone species for aquatic ecosystem conservation in South Africa: The case of the Olifants River', Aquatic Conservation: Marine and Freshwater Ecosystems 20(5), 489-493. https://doi.org/10.1002/aqc.1132

Beland, K.F., Kocik, J.F. \& Sheehan, T.F., 2001, 'Striped bass predation upon Atlantic salmon smolts in Maine', Northeastern Naturalist 8(3), 267-275. https://doi. org/10.2307/3858483

Bengraïne, K. \& Marhaba, T.F., 2003, 'Using principal component analysis to monitor spatial and temporal changes in water quality', Journal of Hazardous Materials 100(1-3), 179-195. https://doi.org/10.1016/S0304-3894(03)00104-3

Block, B.A., Holbrook, C.M., Simmons, S.E., Holland, K.N., Ault, J.S., Costa, D.P. et al., 2016, 'Toward a national animal telemetry network for aquatic observations in the United States', Animal Biotelemetry 4, 6. https://doi.org/10.1186/s40317 015-0092-1

Bolland, J.D., Nunn, A.D., Angelopoulos, N.V., Dodd, J.R., Davies, P., Roberts, C.G. et al., 2019, 'Refinement of acoustic-tagging protocol for twaite shad Alosa fallax (Lacépède), a species sensitive to handling and sedation', Fisheries Research 212, 183-187. https://doi.org/10.1016/j.fishres.2018.12.006

Bouwman, H., Booyens, P., Govender, D., Pienaar, D. \& Polder, A., 2014, 'Chlorinated brominated, and fluorinated organic pollutants in Nile crocodile eggs from the Kruger National Park, South Africa', Ecotoxicology and Environmental Safety 104 393-402. https://doi.org/10.1016/j.ecoenv.2013.12.005

Burnett, M.J., O'Brien, G.C., Jacobs, F.J., Botha, F., Jewitt, G. \& Downs, C.T., 2020 'Southern African inland fish tracking programme (FISHTRAC): An evaluation of the approach for monitoring ecological consequences of multiple water resource stressors, remotely and in real time', Ecological Indicators 111, 106001. https:// doi.org/10.1016/j.ecolind.2019.106001

Burnett, M.J., O'Brien, G.C., Wepener, V. \& Pienaar, D., 2018, 'The spatial ecology of adult Labeobarbus marequensis and their response to flow and habitat variability in the Crocodile River, Kruger National Park', African Journal of Aquatic Science 43(4), 375-384. https://doi.org/10.2989/16085914.2018.1517077

Cooke, S.J., Hinch, S.G., Wikelski, M., Andrews, R.D., Kuchel, L.J., Wolcott, T.G. et al., 2004, 'Biotelemetry: A mechanistic approach to ecology', Trends in Ecology \& Evolution 19(6), 334-343. https://doi.org/10.1016/j.tree.2004.04.003

Cooke, S.J., Midwood, J.D., Thiem, J.D., Klimley, P., Lucas, M.C., Thorstad, E.B. et al., 2013, 'Tracking animals in freshwater with electronic tags: Past, present and future', Animal Biotelemetry 1, 5. https://doi.org/10.1186/2050-3385-1-5

Cooke, S.J., Nguyen, V.M., Kessel, S.T., Hussey, N.E., Young, N. \& Ford, A.T., 2017 'Troubling issues at the frontier of animal tracking for conservation and management', Conservation Biology 31(5), 1205-1207. https://doi.org/10.1111/ cobi.12895

Cooke, S.J. \& Schreer, J.F, 2003, 'Environmental monitoring using physiological telemetry - A case study examining common carp responses to thermal pollution in a coal-fired generating station effluent', Water, Air, and Soil Pollution 142, 113-136. https://doi.org/10.1023/A:1022082003932

Core, R., 2015, R: A language and environment for statistical computing, R Foundation for Statistical Computing, Vienna, Austria.

Cowley, P.D., Terörde, A.I. \& Whitfield, A.K., 2017, 'Birds as major predators of fishes in the East Kleinemonde Estuary', African Zoology 52, 147-154. https://doi.org/ 10.1080/15627020.2017.1361865 
Dabrowski, J., Oberholster, P.J. \& Dabrowski, J.M., 2014, 'Water quality of flag Boshielo Dam, Olifants River, South Africa: Historical trends and the impact of drought', Water SA 40(2), 345-358. https://doi.org/10.4314/wsa.v40i2.17

De Moor, I.J., 1996, 'Case studies of the invasion by four alien fish species (Cyprinus carpio, Micropterus salmoides, Oreochromis macrochir and $O$. mossambicus) of carpio, Micropterus salmoides, Oreochromis macrochir and O. mossambicus) of South Africa 51(1), 233-255. https://doi.org/10.1080/00359199609520609

Department of Environmental Affairs and Tourism, 2007, National environmental management: Biodiversity Act 2004 (Act 10 of 2004): Amendment of critically endangered, endangered, vulnerable and protected species list, No. R. 1187 Department of Environmental Affairs, Pretoria.

De Villiers, S. \& Mkwelo, S.T., 2009, 'Has monitoring failed the Olifants River, Mpumalanga?', Water SA 35(5), 671-676. https://doi.org/10.4314/wsa. v35i5.49193

Du Plessis, A., 2019, 'Evaluation of Southern and South Africa's freshwater resources', in A. Du Plessis (ed.), Water as an inescapable risk, pp. 147-172, Springer, Cham.

Du Preez, H.H. \& Steyn, G.J., 1992, 'A preliminary investigation of the concentration of selected metals in the tissues and organs of the tigerfish (Hydrocynus vittatus) from the Olifants River, Kruger National Park, South Africa', Water SA 18(2) 131-136.

Dudgeon, D., 2014, 'Threats to freshwater biodiversity in a changing world', in B. Freedman (ed.) Global environmental change: Handbook of global environmental pollution, vol. 1, pp. 243-253, Springer, Dordrecht.

Dudgeon, D., Arthington, A.H., Gessner, M.O., Kawabata, Z.I., Knowler, D.J., Lévêque, C. et al., 2006, 'Freshwater biodiversity: Importance, threats, status and conservation challenges', Biological Reviews 81(2), 163-182. https://doi. org/10.1017/S1464793105006950

Ellender, B.R. \& Weyl, O.L., 2014, 'A review of current knowledge, risk and ecological impacts associated with non-native freshwater fish introductions in South Africa', Aquatic Invasions 9(2), 117-132. https://doi.org/10.3391/ai.2014.9.2.01

Ferreira, S.M. \& Pienaar, D., 2011, 'Degradation of the crocodile population in the Olifants River gorge of Kruger National Park, South Africa', Aquatic Conservation: Marine and Freshwater Ecosystems 21(2), 155-164. https://doi.org/10.1002/ Marine 1175

Fouché, P.S.O., 2008, 'Status of the lowveld largescale yellowfish Labeobarbus marequensis (A. Smith, 1841)', in N.D. Impson, I.R. Bills \& L. Wolhuter (eds.) Technical report on the state of yellowfishes in South Africa, WRC Report No. KV 212/08, Water Research Commission, Pretoria.

Frank, H.J., Mather, M.E., Smith, J.M., Muth, R.M., Finn, J.T. \& McCormick, S.D., 2009 "What is "fallback"? Metrics needed to assess telemetry tag effects on anadromous fish behavior', Hydrobiologia 635, 237-249. https://doi.org/10.1007/s10750-0099917-3

Games, I. \& Moreau, J., 1997, 'The feeding ecology of two Nile crocodile population in the Zambezi Valley', in J. Moreau (ed.), Advances in the ecology of Lake Kariba, pp. 183-195, UZ Publications, Harare.

Gerber, R., Smit, N.J., Van Vuuren, J.H. \& Wepener, V., 2016, 'Metal concentrations in Hydrocynus vittatus (Castelnau 1861) populations from a premier conservation area: Relationships with environmental concentrations', Ecotoxicology and Environmental Safety 129, 91-102. https://doi.org/10.1016/j.ecoenv.2016.03.009

Godin, J.G., 1997, Behavioural ecology of teleost fishes, Oxford University Press, Oxford.

Halfyard, E.A., Webber, D., Del Papa, J., Leadley, T., Kessel, S.T., Colborne, S.F. et al., 2017, 'Evaluation of an acoustic telemetry transmitter designed to identify predation events', Methods in Ecology and Evolution 8(9), 1063-1071. https://doi. org/10.1111/2041-210X.12726

Harrison, T.D. \& Whitfield, A.K., 2006, 'Application of a multimetric fish index to assess the environmental condition of South African estuaries', Estuaries and Coasts 29 1108-1120. https://doi.org/10.1007/BF02781813

Horn, J.A., Mateus-Pinilla, N., Warner, R.E. \& Heske, E.J., 2011, 'Home range, habitat use, and activity patterns of free-roaming domestic cats', Journal of Wildlife Management 75(5), 1177-1185. https://doi.org/10.1002/jwmg.145

Hussey, N.E., Kessel, S.T., Aarestrup, K., Cooke, S.J., Cowley, P.D., Fisk, A.T. et al., 2015 'Aquatic animal telemetry: A panoramic window into the underwater world', Science 348(6240), 1-10. https://doi.org/10.1126/science.1255642

Jacobs, F., O'Brien, G. \& Smit, N., 2016, 'Diel movement of smallmouth yellowfish Labeobarbus aeneus in the Vaal River, South Africa', African Journal of Aquatic Science 41(1), 73-76. https://doi.org/10.2989/16085914.2015.1136804

Jacobs, F.J., 2017, The conservation ecology of the African tigerfish Hydrocynus vittatus in the Kavango River, Namibia, PhD thesis, University of KwaZulu-Natal, Pietermaritzburg.

Jacobs, F.J., Naesje, T.F., Ulvan, E.M., Weyl, O.L.F., Tiyeho, D., Hay, C.J. et al., 2019, 'Implications of the movement behaviour of African tigerfish Hydrocynus vittatus for the design of freshwater protected areas', Journal of Fish Biology 1-9. https:// doi.org/10.1111/jfb.14158

Jepsen, N., Koed, A., Thorstad, E.B. \& Baras, E., 2002, 'Surgical implantation of telemetry transmitters in fish: How much have we learned?', Hydrobiologia 483 239-248. https://doi.org/10.1023/A:1021356302311

Jepsen, N., Schreck, C., Clements, S. \& Thorstad, E.B., 2004, 'A brief discussion on the $2 \% \mathrm{tag} /$ body weight rule of thumb', in M.T. Spedicato, G. Lembo. \& G. Marmulla (eds.), Aquatic telemetry: advances and applications. Proceedings of the Fifth Conference on Fish Telemetry held in Europe, Ustica, Italy, 9-13 June 2003, pp. 255-259, Food and Agriculture Organization of the United Nations (FAO)pp. $255-259$, Food and Agriculture
COISPA Tecnologia \& Ricerca, Rome.
Jepsen, N., Thorstad, E.B., Havn, T. \& Lucas, M.C., 2015, 'The use of external electronic tags on fish: An evaluation of tag retention and tagging effects', Animal tags on fish: An evaluation of tag retention and tagging
Biotelemetry 3, 49. https://doi.org/10.1186/s40317-015-0086-z.

Klinard, N.V. \& Matley, J.K., 2020, 'Living until proven dead: Addressing mortality in acoustic telemetry research', Reviews in Fish Biology and Fisheries 22, 1-5. https://doi.org/10.1007/s11160-020-09613-z

Lennox, R.J., Aarestrup, K., Cooke, S.J., Cowley, P.D., Deng, Z.D., Fisk, A.T. et al., 2017 'Envisioning the future of aquatic animal tracking: Technology, science, and application', BioScience 67(10), 884-896. https://doi.org/10.1093/biosci/bix098

McKight, P.E. \& Najab, J., 2010, 'Kruskal-Wallis test', in I.B. Weiner \& W.E. Craighead (eds.), The Corsini Encyclopedia of Psychology. https://doi.org/10.1002/ 9780470479216.corpsy0491

Metcalfe, J.D., Wright, S., Tudorache, C. \& Wilson, R.P., 2016, 'Recent advances in telemetry for estimating the energy metabolism of wild fishes', Journal of Fish Biology 88(1), 284-297. https://doi.org/10.1111/jfb.12804

Mims, M.C. \& Olden, J.D., 2013, 'Fish assemblages respond to altered flow regimes via ecological filtering of life history strategies', Freshwater Biology 58(1), 50-62. https://doi.org/10.1111/fwb.12037

Moxham, E.J., Cowley, P.D., Bennett, R.H. \& Von Brandis, R.G., 2019, 'Movement and predation: A catch-and-release study on the acoustic tracking of bonefish in the Indian Ocean', Environmental Biology of Fishes 102, 365-381. https://doi. org/10.1007/s10641-019-00850-1

Nasir, M.F.M., Samsudin, M.S., Mohamad, I., Awaluddin, M.R.A., Mansor, M.A., Juahir H. et al., 2011, 'River water quality modeling using combined principle component analysis (PCA) and multiple linear regressions (MLR): A case study at Klang River, Malaysia', World Applied Sciences Journal 14, 73-82.

O’Brien, G.C., Bulfin, J.B., Husted, A. \& Smit, N.J., 2012, 'Comparative behavioural assessment of an established and a new tigerfish Hydrocynus vittatus population in two man-made lakes in the Limpopo River catchment, southern Africa', African Journal of Aquatic Science 37(3), 253-263. https://doi.org/10.2989/16085914.20 12.723196

O’Brien, G.C., Dickens, C., Hines, E., Wepener, V., Stassen, R., Quayle, L. et al., 2018, 'A regional-scale ecological risk framework for environmental flow evaluations' Hydrology and Earth System Sciences 22(2), 957-975. https://doi.org/10.5194/ hess-22-957-2018

O’Brien, G.C., Jacobs, F., Cronje, L., Wepener, V. \& Smit, N.J., 2013, 'Habitat preferences and movement of adult yellowfishes in the Vaal River, South Africa', South African and movement of adult yellowfishes in the Vaal River, South Africa', South African
Journal of Science 109(7/8), 1-8. https://doi.org/10.1590/sajs.2013/20120095

O'Brien, G.C., Jacobs, F., Evans, S.W. \& Smit, N.J., 2014, 'First observation of African tigerfish Hydrocynus vittatus predating on barn swallows Hirundo rustica in flight', Journal of Fish Biology 84(1), 263-266. https://doi.org/10.1111/jfb.12278

O’Brien, G.C., Ross, M., Hanzen, C., Dlamini, V., Petersen, R., Diedericks, G.J. et al., 2019, 'River connectivity and fish migration considerations in the management of multiple stressors in South Africa', Marine and Freshwater Research 70(9) 1254-1264. https://doi.org/10.1071/MF19183

O'Brien, G.C., Swemmer, R. \& Wepener, V., 2009, 'Ecological integrity assessment of the fish assemblages of the Matigulu/Nyoni and Umvoti estuaries, KwaZulu-Natal, South Africa', African Journal of Aquatic Science 34(3), 293-302. https://doi. org/10.2989/AJAS.2009.34.3.11.987

$\varnothing$ kland, F., Thorstad, E.B., Hay, C.J., Næsje, T.F. \& Chanda, B., 2005, 'Patterns of movement and habitat use by tigerfish (Hydrocynus vittatus) in the Upper Zambezi River (Namibia)', Ecology of Freshwater Fish 14(1), 79-86. https://doi. org/10.1111/j.1600-0633.2004.00080.x

Østnes, J.E., Kroglund, R.T., Kleven, O. \& Nygård, T., 2019, 'Migratory patterns of ospreys (Pandion haliaetus) from central Norway', Ornis Fennica 96(3), 101-111.

Paukert, C.P., Chvala, P.J., Heikes, B.L. \& Brown, M.L., 2001, 'Effects of implanted transmitter size and surgery on survival, growth, and wound healing of bluegill', Transactions of the American Fisheries Society 130(5), 975-980. https://doi. Transactions of the American Fisheries Society 130(5), 975-980.
org/10.1577/1548-8659(2001)130\%3C0975:EOITSA\%3E2.0.CO;2

Pearce, F., 2018, When the rivers run dry, water-the defining crisis of the twenty-first century, Beacon Press, Boston, MA

Pienaar, U.D.V., 1964, 'The small mammals of the Kruger National Park-A systematic list and Zoogeography', Koedoe 7(1), 1-25. https://doi.org/10.4102/koedoe.v7i1.795

Pollard, S., Mallory, S., Riddell, E. \& Sawunyama, T., 2012, Towards improving the assessment and implementation of the reserve: Real-time assessment and implementation of the ecological reserve, Report, Water Research Commission, Pretoria.

Rodell, M., Famiglietti, J.S., Wiese, D.N., Reager, J.T., Beaudoing, H.K., Landerer, F.W. et al., 2018, 'Emerging trends in global freshwater availability', Nature 557, 651-659. https://doi.org/10.1038/s41586-018-0123-1

Rogers, K.H. \& O'Keeffe, J., 2003, 'River heterogeneity: Ecosystem structure, function and management', in A.R. Sinclair \& B. Walker (eds.), The Kruger experience: Ecology and management of savanna heterogeneity, pp. 189-218, Island Press, Washington, DC

Roux, D.J., Nel, J.L., Ashton, P.J., Deacon, A.R., De Moor, F.C., Hardwick, D. et al., 2008, 'Designing protected areas to conserve riverine biodiversity: Lessons from a hypothetical redesign of the Kruger National Park', Biological Conservation 141(1), 100-117. https://doi.org/10.1016/j.biocon.2007.09.002

Roux, F., Steyn, G., Hay, C. \& Wagenaar, I., 2018, 'Movement patterns and home range size of tigerfish (Hydrocynus vittatus) in the Incomati River system, South Africa' Koedoe 60(1), 1-3. https://doi.org/10.4102/koedoe.v60i1.1397

Rowe-Rowe, D.T., 1977, 'Food ecology of otters in Natal, South Africa', Oikos 28(2/3), 210-219. https://doi.org/10.2307/3543973

Schultz, A.A., Afentoulis, V.B., Yip, C.J. \& Johnson, M.N., 2017, 'Efficacy of an acoustic tag with predation detection technology', North American Journal of Fisheries Management 37(3), 574-581. https://doi.org/10.1080/02755947.2017.1290720 
Sequeira, A.M.M., Heupel, M.R., Lea, M.A., Eguíluz, V.M., Duarte, C.M., Meekan, M.G. et al., 2019, 'The importance of sample size in marine megafauna tagging studies', Ecological Applications 29(6), 1344-1360. https://doi.org/10.1002/eap.1947

Skalski, J.R., Richins, S.M. \& Townsend, R.L., 2018, 'A statistical test and sample size recommendations for comparing community composition following PCA', PLOS One 13(10), 1-19. https://doi.org/10.1371/journal.pone.0206033

Smit, N.J., Wepener, V., Vlok, W., Wagenaar, G.M. \& Van Vuuren, J.H.J., 2013 Conservation of tigerfish, Hydrocynus vittatus, in the Kruger National Park with the emphasis on establishing the suitability of the water quantity and quality requirements for the Olifants and Luvuvhu rivers, WRC Report No. 1922/1/12 Water Research Commision, Pretoria.

Sosa-López, A., Mouillot, D., Do Chi, T. \& Ramos-Miranda, J., 2005, 'Ecological indicators based on fish biomass distribution along trophic levels: An application to the Terminos coastal lagoon, Mexico', ICES Journal of Marine Science 62(3), 453-458. https://doi.org/10.1016/j.icesjms.2004.12.004

Stears, K. \& McCauley, D.J., 2018, 'Hippopotamus dung inputs accelerate fish predation by terrestrial consumers', African Journal of Ecology 56(4), 1034-1038. predation by terrestrial consumers',
https://doi.org/10.1111/aje.12543

Stewart, K., Matthiesen, D., Leblanc, L. \& West, J., 1997, 'Prey diversity and selectivity of the African fish eagle: Data from a roost in northern Kenya', African Journal of Ecology 35(2), 133-145. https://doi.org/10.1111/j.1365-2028.1997.066-89066.x

Steyn, G.J., Gagiano, C.L., Deacon, A.R. \& Du Preez, H.H., 1996, 'Notes on the induced reproduction and development of the tigerfish, Hydrocynus vittatus (Characidae) embryos and larvae', Environmental Biology of Fishes 47, 387-398. https://doi. org/10.1007/BF00005052
Thorstad, E.B., Hay, C.J., Næsje, T.F., Chanda, B. \& Økland, F., 2003, 'Space use and habitat utilisation of tigerfish and the two cichlid species nembwe and threespot tilapia in the Upper Zambezi River', in Implications for fisheries management, NINA Project Report No. 24, pp. 1-22, Norwegian Institute for Nature Research, NINA Project Report
Trondheim, Norway.

Thorstad, E.B., Rikardsen, A.H., Alp, A. \& Økland, F., 2013, 'The use of electronic tags in fish research - An overview of fish telemetry methods', Turkish Journal of in fish research - An overview of fish telemetry methods', Turkish Journal of
Fisheries and Aquatic Sciences 13, 881-896. https://doi.org/10.4194/1303Fisheries and 2712 -v13_5_13

Thronson, A. \& Quigg, A., 2008, 'Fifty-five years of fish kills in coastal Texas', Estuaries and Coasts 31, 802-813. https://doi.org/10.1007/s12237-008-9056-5

Van Den Brink, P.J., Van Den Brink, N.W. \& Ter Braak, C.J., 2003, 'Multivariate analysis of ecotoxicological data using ordination: Demonstrations of utility on the basis of various examples', Australasian Journal of Ecotoxicology 9(2), 141-156.

Vignaud, P., Duringer, P., Mackaye, H.T., Likius, A., Blondel, C., Boisserie, J.R. et al., 2002, 'Geology and palaeontology of the Upper Miocene Toros-Menalla hominid locality, Chad', Nature 418, 152-155. https://doi.org/10.1038/nature00880

Wisniewska, D.M., Johnson, M., Teilmann, J., Rojano-Doñate, L., Shearer, J., Sveegaard, S. et al., 2016, 'Ultra-high foraging rates of harbor porpoises make them vulnerable to anthropogenic disturbance', Current Biology 26(11), 1441-1446. https://doi. org/10.1016/j.cub.2016.03.069

Woodborne, S., Huchzermeyer, K.D.A., Govender, D., Pienaar, D.J., Hall, G., Myburgh, J.G. et al., 2012, 'Ecosystem change and the Olifants River crocodile mass mortality events', Ecosphere 3(10), 1-17. https://doi.org/10.1890/ES12-00170.1 